\title{
Effects of Acute Stress on Learning and Memory Processes of Malnourished Rats
}

\author{
Efeitos do Estresse Agudo em Processos de Aprendizagem e Memória \\ de Ratos Desnutridos
}

\author{
Lucas Duarte Ferreira Manhas dos Vales ${ }^{a}$, Marisa Tomoe Hebihara Fukuda ${ }^{b}$ \\ \& Sebastião Sousa Almeida*,a \\ ${ }^{a}$ Faculdade de Filosofia, Ciências e Letras da Universidade de São Paulo, Ribeirão Preto, SP, Brasil \\ $\&{ }^{a}$ Faculdade de Medicina da Universidade de São Paulo, Ribeirão Preto, SP, Brasil
}

\begin{abstract}
The aim of the study was to investigate the effects of acute stress on the processes of learning and memory in malnourished rats tested in the Morris water maze. The animals were divided into eight groups according to nutritional status (malnourished or well nourished) and stress (stressed or unstressed). In Experiment I the animals were subjected to immobilization stress procedure before the learning session and in Experiment II after the learning sessions. The test consisted of two daily sessions, and a memory test after four weeks. There was loss of learning and memory in malnourished rats. In Experiment I the malnourished group was positively affected by acute stress, with significant improvement of performance. No effects of stress on the animals' performance in Experiment II were observed. In the memory test, the malnourished rats showed deficits in consolidation and recall, regardless of the occurrence of stress. The stress imposed 24 hours before the learning task improved performance of malnourished animals with a protective effect of stress. However there was no improvement in the processes of retention or recall from memory (previously learned information) assessed four weeks later, during the memory retention test.

Keywords: Protein malnutrition, acute stress, learning, spatial memory.

\section{Resumo}

O objetivo do estudo foi investigar os efeitos do estresse agudo sobre os processos de aprendizagem e memória em ratos desnutridos testados no labirinto aquático de Morris. Os animais foram divididos em oito grupos de acordo com a condição nutricional (desnutridos ou bem nutridos) e estresse (não estressados ou estressados). No Experimento I os animais foram submetidos ao procedimento de estresse por imobilização antes da sessão de aprendizagem e no Experimento II após as sessões de aprendizagem. O teste consistiu de duas sessões diárias e um teste de memória após quatro semanas. Houve prejuízos de aprendizagem e memória em ratos desnutridos. No Experimento I o grupo desnutrido foi positivamente afetado pelo estresse agudo, apresentando melhora significativa de desempenho. Não foram observados efeitos do estresse sobre o desempenho dos animais no Experimento II. No teste de memória os ratos desnutridos apresentaram déficits de consolidação e evocação, independentemente da ocorrência de estresse. O estresse imposto 24 horas antes da tarefa de aprendizagem melhorou o desempenho de animais desnutridos com um efeito protetor do estresse. Entretanto não houve melhora nos processos de retenção ou evocação da memória (informações previamente aprendidas), avaliados quatro semanas mais tarde, durante o teste de retenção de memória. Palavras-chave: Desnutrição proteica, estresse agudo, aprendizagem e memória espacial.
\end{abstract}

Nutritional function is directly implicated in formation, development, functional organization, biochemical and morphological maturation of the organism, especially

\footnotetext{
Mailing address: Laboratory of Nutrition and Behavior, Department of Psychology, University of São Paulo, Avenida dos Bandeirantes, 3900, Ribeirão Preto, SP, Brazil 14040-901. E-mail: sebasalm@usp.br This research was supported by research grants from Coordination of Improvement of Higher Education Personnel (CAPES-Brazil), National Council for Scientific and Technological Development (CNPq-Brazil; 470446/2006-4) and Foundation for Research Support of the State of São Paulo (FAPESP-Brazil; 2006/02917-5).
}

during the early stages of development (Galler, Shumsky, \& Morgane, 1995; Morgane et al., 1993; Morgane, Mokler, $\&$ Galler, 2002). Disorders related to nutritional functions, more specifically protein malnutrition, occurring during the prenatal period and/or at the beginning of life, can produce structural, neurochemical and neurophysiological changes in the central nervous system (CNS; Almeida, Tonkiss, \& Galler, 1996a; Galler et al., 1995; Morgane et al., 1993; Morgane et al., 2002), and consequent behavioral changes (Almeida, De-Oliveira, \& Graeff, 1991; Camargo \& Almeida, 2005), and learning and memory deficits 
Vales, L. D. F. M., Fukuda, M. T. H. \& Almeida, S. S. (2014). Effects of Acute Stress on Learning and Memory Processes of Malnourished Rats.

(Fukuda, Françolin-Silva, \& Almeida, 2002; Fukuda, Françolin-Silva, Hernandes, Valadares, \& Almeida, 2007; Valadares, Fukuda, Françolin-Silva, Hernandes, \& Almeida, 2010; Wolf, Almli, Finger, Ryan, \& Morgane, 1986; Zhang, Li, \& Yang, 2010) as observed later, in the adulthood. Even in adulthood, a protein deprivation insult produces marked loss of hippocampal neurons and synapses accompanied by significant impairments of hippocampal-dependent behaviors (Lukoyanov \& Andrade, 2000). Therefore, malnutrition is a major environmental factor affecting CNS development, causing long-lasting cognition impairments (for a review see Laus, Vales, Costa, \& Almeida, 2011).

Experimental studies with rats have demonstrated impaired development and growth of pups when malnutrition was introduced during the lactation period (Crnic \& Chase, 1978; Hernandes, Françolin-Silva, Valadares, Fukuda, \& Almeida, 2005), as a consequence of a reduced supply and altered quality of maternal milk (Passos, Ramos, \& Moura, 2000; Pine, Jessop, \& Oldham, 1994).

Among the CNS regions impaired by early malnutrition, one particularly affected structure is the hippocampus (Cintra, Díaz-Cintra, Galvan, Kemper, \& Morgane, 1990; Matos, Orozco-Solís, Lopes de Souza, Manhãesde-Castro, \& Bolños-Jiménez, 2011; Zhang et al., 2010). The neurogenesis of this structure extends to postnatal period, reaching one of its growth and development peaks during this period (Morgane et al., 2002). Changes in the hippocampal function such as deficits of synaptic contacts and on neurotransmitter systems are correlated with learning and spatial memory deficits (Bedi, 1991; Cintra et al., 1990; Fukuda et al., 2007; Lukoyanov \& Andrade, 2000; Morgane et al., 1993; Morgane et al., 2002; Zhang et al., 2010). Pharmacological, molecular and electrophysiological studies had shown evidences that the hippocampus is a structure involved in the learning and memory processes, in the formation of a spatial cognitive map (Bedi, 1992; Lukoyanov \& Andrade, 2000; O'Keefe \& Nadel, 1978; Olton, 1979), and also in the neuroendocrine regulation of stress hormones and consequently in the behavioral response due to stress situations (Kim \& Diamond, 2002; Margis, Picon, \& Cosner, 2003; McEwen, 2000; McEwen \& Sapolsky, 1995; Quevedo, Feier, Agostinho, Martins, \& Roesler, 2003). The responses of the organisms to stress situations involve adaptive mechanisms to react in an effective way to real or potential threats to survival (Kim \& Diamond, 2002; McEwen, 2000; McEwen \& Sapolsky, 1995).

The hippocampus participates in the process of response regulation to stress by glucocorticoid-mediated negative feedback which inhibits the hypothalamuspituitary-adrenal axis (HPA; McEwen, 2000; McEwen \& Sapolsky, 1995). The rates of secretion of these neurotransmitters can vary according to stress intensity and there is no consistent pattern of catecholamine and glucocorticoid activation in response to stressor events (McEwen \& Sapolsky, 1995). The modulation of hippocampal function by stress involves a dynamic process which is under the continuous influence of environmental stimuli perceived by the animal (Kim \& Diamond, 2002). Immobilization procedures are considered to be effective stressors able to produce both physiological and behavioral changes (Dronjak, Gavrilović, Filipović, \& Radojcić, 2004; Rosa et al., 2005).

In malnourished animals, as a consequence of previously reported changes in several neurotransmission systems (Almeida et al., 1996a), it has been described alterations in risk-assessment behaviors (Almeida et al., 1991), reactivity to aversive stimuli (Almeida \& DeOliveira, 1994; Rocinholi, Almeida, \& De-Oliveira, 1997), as well as in learning and memory (Hemb, Cammarota, \& Nunes, 2010; Fukuda et al., 2007; Valadares et al., 2010; Wolf et al., 1986; Zhang et al., 2010).

Learning and memory in malnourished rats were originally studied using mazes as experimental models (Olton, 1979), and the Morris water maze (MWM) has been the most frequently used procedure (D'Hooge \& De Deynn, 2001). In the distal clue version of the MWM, the rat must swim to a specific place based only on the information outside the apparatus using a spatial mapping system. The main response recorded in this system in order to evaluate learning and memory of the rats is the escape latency (time spent to complete the task, i.e., find the submerged platform and escaping from water). This model is particularly interesting to study the early malnutrition procedures, since no food reward is required, since food reward could be a confounding variable when testing animals malnourished in the beginning of life. In addition, any kind of food reward could serve as a visual and/or olfactory clue and, possibly, produce differentially motivated responses toward the food in malnourished animals (Barnes, Neely, Kwong, Labadan, \& Franková, 1968).

Aversive stimuli situations are frequent natural events in everyday life. Rats exposed to unfamiliar situations or aversive stimuli generally exhibit behavioral changes due to response strategies to stress (Kim \& Diamond, 2002; McEwen, 2000; McEwen \& Sapolsky, 1995). Furthermore, malnourished rats show a pattern of behavioral changes in response to aversive stimuli in different stress situations (Almeida \& De-Oliveira, 1994; Françolin-Silva \& Almeida, 2004; Rocinholi et al., 1997). Stress has been described as a possible anxiogenic factor in early malnourished rats when assessed in the elevated plus maze (EPM; Françolin-Silva \& Almeida, 2004), but learning and memory have never been studied in rats undernourished in early life and subjected to acute stress in adulthood. The objective of this study was to investigate, in the Morris water maze, the effects of acute stress (and the moment of its occurrence) on the processes of learning and memory in adult rats undernourished in early life. 


\section{Method}

\section{Animals and Diet}

One hundred two male Wistar rats from the Central Animal Facilities of the Ribeirão Preto Campus, University of São Paulo were used. The study was approved by the Ethics Committee for the Use of Animals (CEUA) of the Ribeirão Preto Campus. The rats were received on the day of birth and divided into groups of litters of 8 pups each (6 males and 2 females) plus the dam.

During the lactation phase, the litters were housed in $41 \times 34 \times 16 \mathrm{~cm}$ polypropylene cages lined with wood chips and covered with a wire mesh lid. During this phase, the dams received isocaloric diets containing $16 \%$ protein (control group) or $6 \%$ protein (malnourished group). The animals of both groups were weaned at 21 days and the male animals housed in pairs in cages of the same size and material described above, and fed the same diets until 49 days of age. During the experiments the animals were housed and treated in the Nutrition and Behavior Animal Facilities under conditions of controlled temperature $\left(23^{\circ} \mathrm{C}\right.$ $+1)$ and a 12 hour light/dark cycle. The rats were weighed every week, from the day of birth (day 0) until the beginning of the tests on MWM (day 70).

Table 1
The diets used were prepared and modified as previously described (Barnes et al., 1968; Santucci, Daud, Almeida, \& De-Oliveira, 1994) and were based on the recommendations of the American Institute of Nutrition (AIN-93) and the Association of Official Agriculture Chemists (AOAC; Reeves, Nielsen, \& Fahey, 1993). The control diet consisted of $16 \%$ protein (casein), $69.8 \%$ cornstarch, $8 \%$ lipids (corn oil), 5\% salt mixture, 1\% vitamin mixture, $.2 \%$ choline, and methionine $(2 \mathrm{~g} / \mathrm{kg}$ casein). The low-protein diet consisted of $6 \%$ protein, $79.8 \%$ cornstarch and the same proportions of the remaining nutrients present in the control diet. On the $49^{\text {th }}$ day of age control and malnourished animals started to receive a commercial lab chow (NUVILAB CR-1, Brazil), $22 \%$ protein, which was continued up to 70 days of age, when the behavioral tests were started. The period between the $49^{\text {th }}$ and $70^{\text {th }}$ days corresponded to the nutritional recovery period for the early malnourished rats.

Two experiments were performed: Experiment I ( $n$ $=52)$ and Experiment II $(n=50)$. The rats were divided into groups according to their nutritional condition during the lactation and post-lactations phases (C: non-stressed control and M: non-stressed malnourished group) and according to exposure to stress before or after the learning task (SC: stressed control and SM: stressed malnourished group), as indicated in Table 1.

Experimental Groups According to their Nutritional Condition and Exposure to Stress

Groups $\quad$ Immobilization

Experiment I

Control (C)

Stressed control (SC)

Malnourished (M)

Stressed malnourished (SM)

Experiment II

Control (C)

Stressed control (SC)

Malnourished (M)

Stressed malnourished (SM)

Note. Experimental design.

\section{Materials and Procedure}

A water maze similar to the model described by Morris (1981) was used. The maze consisted of a circular fiberglass white tank $150 \mathrm{~cm}$ in diameter and $39 \mathrm{~cm}$ high filled with water at a controlled temperature of $25^{\circ} \mathrm{C} \mathrm{(+}$ $\left.1^{\circ} \mathrm{C}\right)$. The tank was divided into four imaginary quadrants numbered in a clockwise direction (quadrants 1,2, 3 and 4). A circular platform $12 \mathrm{~cm}$ indiameter and $25 \mathrm{~cm}$ high was placed inside the tank in a fixed position in the center of one of the four imaginary quadrants (quadrant 1). Milk (2 liters) was used to render the water opaque and to hide the
24 hours before the test

-

24 hours before the test

After the last trial on the first and second day of the test.

After the last trial on the first and second day of the test.

platform which was submerged $1.5 \mathrm{~cm}$ below water level.

The water maze was placed in the center of a room. Visual clues were present in areas outside the tank such as figures on the walls, windows and door, to be used as distal learning clues for the rats. No close visual, olfactory or auditory clues were offered. Experimental sessions were recorded by a video camera connected to a video system, for further analysis.

Movement restriction devices made of stainless steel were used for the stress immobilization procedure. The devices were of two sizes $(22 \times 7.5 \times 6 \mathrm{~cm}$ for control rats 
Vales, L. D. F. M., Fukuda, M. T. H. \& Almeida, S. S. (2014). Effects of Acute Stress on Learning and Memory Processes of Malnourished Rats.

and $20 \times 6.5 \times 5 \mathrm{~cm}$ for malnourished rats), with a flat base and a convex and adjustable upper part, similar tothe stress device described by Rosa et al. (2005).

Stress Procedure. Rats were assigned at random to the SC and SM groups in each experiment. The animalswere placed in the restraining device for 1 hour and, after this period of stress, were removed from the device and returned to the animal facilities. During the stress period the rats were placed in an adjacent room free of noise and of same light intensity.

Experiment I. In Experiment I, the SC and SM groups were subjected to the stress period at 70 days oflife, 24 hours before the first of the two experimental sessions in the MWM.

Before the first trial of the first day of the test each rat was placed on the platform for 60 seconds. After this time, the rat was placed with its back turned to the center of the tank in one of the quadrants, except the one where the platform was located, and was allowed to swim for a period of 60 seconds in order to find the escape platform. The platform was left in the same location throughout the experiment. Twelve daily trials were held over two consecutive days. When the rat was unable to reach the platform within the established time it was removedfrom the water and placed on the platform. Trials were separated by 35 seconds and during this period the animal remained over the platform. The positions in which the animals were placed during each trial were determined at random in equal proportions. After the last trial of the second day of test the platform was removed and the rat was placed in the quadrant diagonally opposite to quadrant containing the platform and allowed to swim for 60 seconds (probe trial $-25^{\text {th }}$ trial). The percentage of time spent in each quadrant was recorded and analyzed.

Twenty-eight days after the end of this phase, each rat was subjected to a single trial $\left(26^{\text {th }}\right)$ for the memory retention test (ability to recover and reuse the information processed in the first stage of the test). The rats were placed in the MWM in the quadrant diagonally opposite to that containing the platform. In this trial each rat had 180 seconds to find the submerged platform. The rats were

Experiment II. In Experiment II, the SC and SM groups were stressed after the first and second session in not stressed before the $26^{\text {th }}$ trial.

the MWM. The same experimental protocol as described in Experiment I was used, except for the time when the animals were stressed.

Data Analysis

Dam's body weight during lactation period were submitted to a two-factor (diet $\mathrm{x}$ day of lactation) analysis of variance (ANOVA), with day factor as a repeated measure. Pup's body weight during lactation and postlactation periods were submitted to a two-factor (diet $\mathrm{x}$ day of age) ANOVA, with day factor as a repeated measure. Behavioral data were submitted to three-factor (diet $\mathrm{x}$ stress $\mathrm{x}$ trial) ANOVA, with trial as a repeated factor. Probe trial data were submitted to three factor (diet $\mathrm{x}$ stress $\mathrm{x}$ quadrant) ANOVA. Post-hoc analyses were conducted using Newman-Keuls test $(p<.05)$.

\section{Results}

\section{Body Weight}

Protein malnutrition produced a decreased weight gain of malnourished litters as compared to control ones, as demonstrated in Table 2. According to ANOVA, there was a significant effect of diet $F(1,41)=336.3 ; p<.05$, with lower weights of malnourished animals. There were also observed significant effects of day of age $F(3,123)=$ $771.1 ; p<.05$ and diet by day of age interaction $F(3,123)$ $=327.1 ; p<.05$. Post-hoc analysis showed lower weight gain of malnourished pups as compared to control ones over the three weeks of lactation period. Malnourished pups' body weight corresponded to $75 \%, 50 \%$ and $35 \%$ of control animals' body weight at the $1^{\text {st }}, 2^{\text {nd }}$ and $3^{\text {rd }}$ weeks of the lactation period, respectively.

Body weight during post-lactation period revealed a significant effect of diet $F(1,107)=751.2 ; p<.05$, with malnourished animals weighing less as compared with control ones. There were also significant effects of day of lactation $F(7,749)=3451.8 ; p<.05$ and diet by day of lactation interaction $F(7,749)=245.8 ; p<.05$. Post-hoc analysis showed lower weight gain of malnourished pups as compared to control ones, despite the rehabilitation period, until the end of the tests when animals were 98 days old (Table 2). Malnourished animals' body weight corresponded to $40 \%$ and $66 \%$ of control animals' body weight at 70 (beginning of behavioral tests) and 98 days of age (end of experiments), respectively.

Table 2

Mean Body Weights of Both Diet Groups, During Nutritional Treatment with Experimental Diets and Nutritional Rehabilitation

\begin{tabular}{lccccc}
\hline \multirow{2}{*}{ Experimental Group } & \multicolumn{3}{c}{ Lactation Phase $(\mathrm{g})$} & \multicolumn{2}{c}{ Adulthood - Nutritional Rehabilitation $(\mathrm{g})$} \\
\cline { 2 - 6 } & $1^{\text {st }}$ week & $2^{\text {nd }}$ week & $3^{\text {rd }}$ week & $70^{\text {th }}$ day & $98^{\text {th }}$ day \\
\hline $\mathrm{C}(n=54)$ & $166.4 \pm 4.5$ & $286.1 \pm 11.7$ & $443.9 \pm 17.0$ & $426.1 \pm 8.9$ & $556.5 \pm 9.2$ \\
$\mathrm{M}(n=48)$ & $126.4 \pm 2.2 *$ & $143.1 \pm 2.4 *$ & $154.9 \pm 4.8 *$ & $171.0 \pm 4.2 *$ & $369.2 \pm 6.3 *$ \\
\hline
\end{tabular}

Note. Body weight $($ Mean \pm SEM);

${ }^{*} p<.05$ compared to $\mathrm{C}$. 


\section{Behavioral Data}

Experiment I. The escape latencies in the Morris maze were significantly reduced during the period of the trials evidencing a significant effect of the trial factor, i.e., learning, $F(23,1104)=9.4 ; p<.05$. There was also a significant effect of the diet factor $F(1,48)=5.1 ; p<.05$, with malnourished animals exhibiting longer latencies as compared to control ones. ANOVA also revealed a significant diet $\mathrm{x}$ stress interaction $F(1,48)=9.7 ; p<.05$. Post hoc analysis showed that the immobilization stress reduced escape latencies on malnourished animals $(p<$ .05 ), but did not affect the control ones (Figure 1A).

(A)

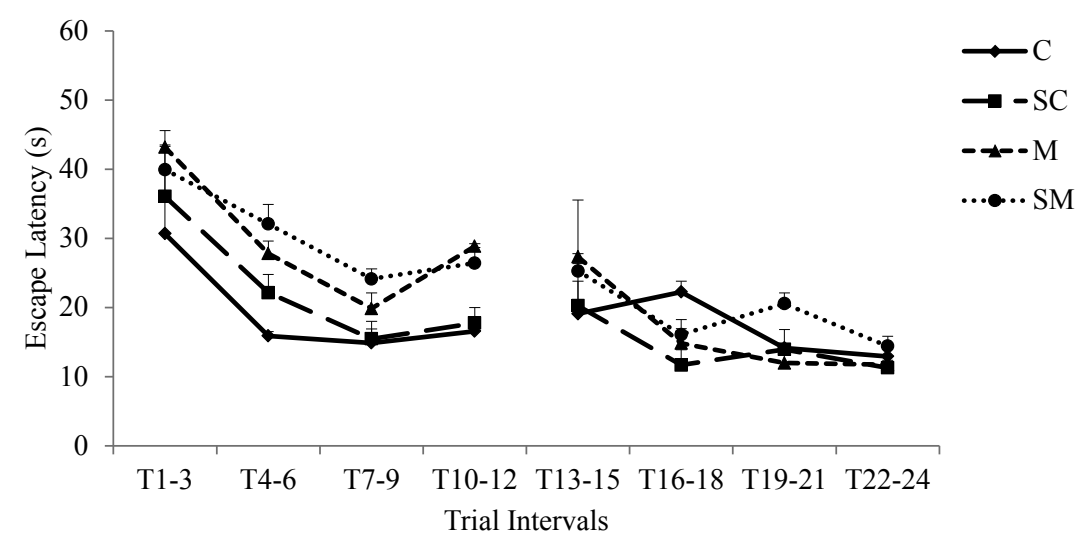

(B)

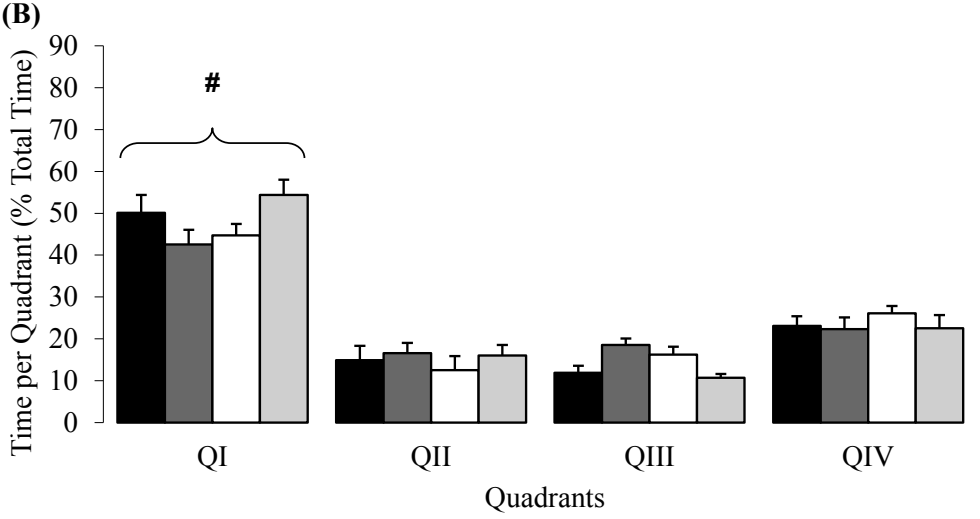

(C)

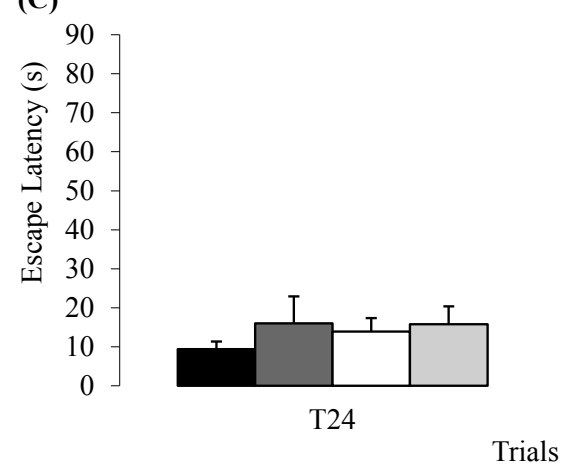

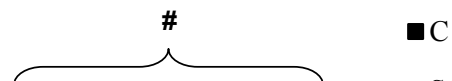

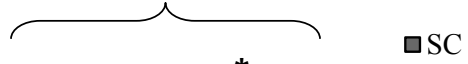

$\square \mathrm{M}$

$\square \mathrm{SM}$

Figure 1. A: Escape latency (Mean + SEM) of the 4 groups in Experiment I, C $(n=14)$, SC $(n=14), \mathrm{M}(n=12), \mathrm{SM}(n=12)$, in the 24 trials of the first phase of MWM test. B: Percent time spent in each of the four quadrants of the MWM (Mean + SEM) by animals of the four groups on probe trial in Experiment I. ${ }^{*} p<.05$ compared to the other groups in QI; \# $p<.05$ compared to time spent in QII, QIII e QIV (Newman-Keuls test). C: Escape latency (Mean + SEM) of the 4 groups in Experiment I, in the last trial of the first phase $\left(24^{\text {th }}\right.$ trial) and 28 days later $\left(26^{\text {th }}\right.$ trial). $\# p<.05$ compared to $24^{\text {th }}$ trial; ${ }^{*} p<.05$ compared to escape latency of the same groups (M and SM) in $24^{\text {th }}$ trial (Newman-Keuls test). 
Vales, L. D. F. M., Fukuda, M. T. H. \& Almeida, S. S. (2014). Effects of Acute Stress on Learning and Memory Processes of Malnourished Rats.

(A)

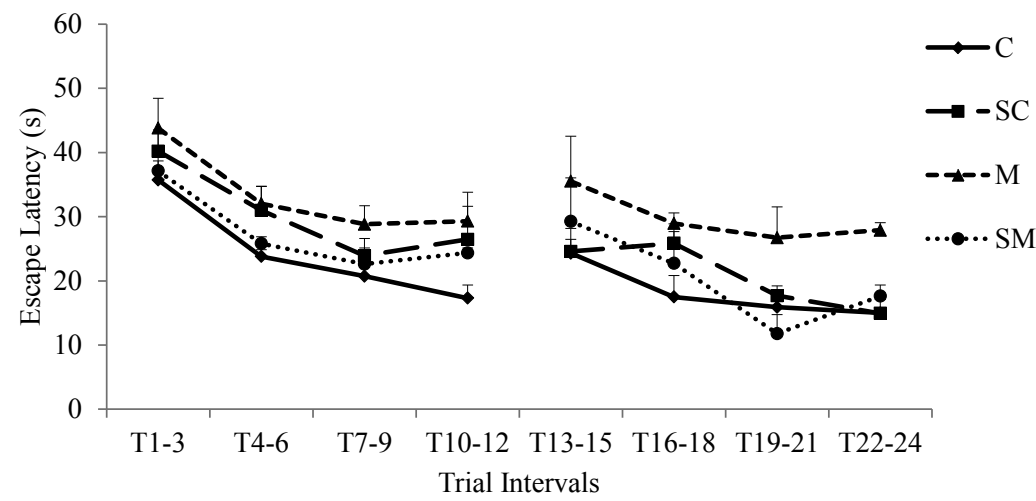

(B)
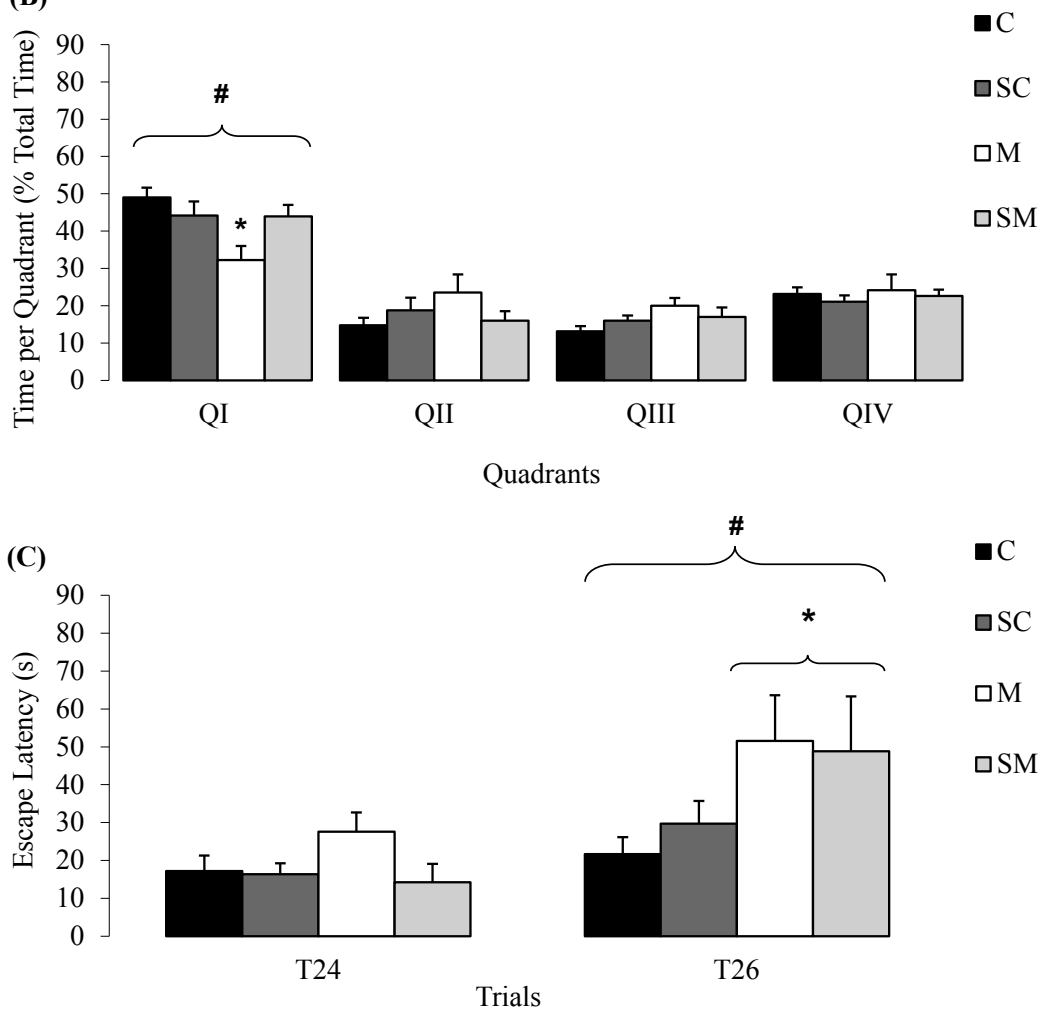

Figure 2. A: Escape latency (Mean + SEM) of the 4 groups in Experiment II, C $(n=14)$, SC $(n=12), \mathrm{M}(n=12), \mathrm{SM}(n=12)$, in the 24 trials of the first phase of MWM test. B: Percent time spent in each of the four quadrants of the MWM (Mean + SEM) by animals of the four groups on probe trial in Experiment II. \# $p<.05$ compared to QII, QIII e QIV (Newman-Keuls test). C: Escape latency (Mean + SEM) of the 4 groups in Experiment II, in the last trial of the first phase ( $24^{\text {th }}$ trial) and 28 days later $\left(26^{\text {th }}\right.$ trial $)$. $\# p<.05$ compared to $24^{\text {th }}$ trial; $* p<.05$ compared to controls in the same trial and to malnourished and control animals in the $24^{\text {th }}$ trial (Newman-Keuls test).

Probe trial data revealed a significant effect of quadrant $F(3,147)=54.5 ; p<.05$, indicating that animals of all groups spent higher time on target quadrant (QI) as compared with all other quadrants. There was also a significant diet $\mathrm{x}$ quadrant interaction $F(3,147)=3.2 ; p<.05$, and a significant diet $\mathrm{x}$ stress $\mathrm{x}$ quadrant interaction $F(3,147)=$ 3.4; $p<.05$. Post hoc analysis showed that the $\mathrm{M}$ group spent shorter time on the target quadrant (QI) as compared to all other groups $(p<.05 ;$ Figure $1 \mathrm{~B})$. Here again the MS group's scores were similar to the control groups.

Regarding the memory retention test, ANOVA revealed a significant effect of trial $F(1,48)=13.3 ; p<.05$, with a higher latency on the $26^{\text {th }}$ trial (retention test trial) as compared to the $24^{\text {th }}$ trial (last trial of the learning phase). There was also a significant effect of $\operatorname{diet} F(1,48)=7.4$; $p<.05$, with malnourished animals (M and SM) showing higher escape latencies as compared with control animals $(p<.05)$, regardless the stress condition (Figure 1C). 
Experiment II. ANOVA revealed a significant effect of $\operatorname{diet} F(1,46)=12.8 ; p<.05$, trial, i.e., learning, $F(23,1058)$ $=14.4 ; p<.05$, and of diet $\mathrm{x}$ trial interaction $F(23,1058)$ $=2.3 ; p<.05$. These results indicated that the animals of the two nutritional groups reduced the time spent to find the hidden platform during succeeding trials and that the performance of the control group was better than that of the malnourished group. Post hoc analysis showed that malnourished rats had longer latencies than controls regardless of the presence of the immobilization stress variable (Figure 2A).

The probe trial data showed a significant effect of quadrant $F(3,123)=99.1 ; p<.05$ and of diet $\mathrm{x}$ stress $\mathrm{x}$ quadrant interaction $F(3,123)=3.5 ; p<.05$. Post hoc analysis showed higher time spent on the target quadrant (QI) as compared to all other quadrants for all experimental groups (Figure 2B).

The retention test data showed a significant effect of $\operatorname{diet} F(1,46)=8.4 ; p<.05$, trial $F(1,46)=23.9 ; p<.05$ and the diet $\mathrm{x}$ trial interaction $F(1,46)=7.6 ; p<.05$. Post hoc analysis showed that $\mathrm{M}$ and $\mathrm{SM}$ rats had longer latencies in the $26^{\text {th }}$ trial compared to controls in the same trial and to malnourished and control animals in the $24^{\text {th }}$ trial. This data highlights the memory deficit of undernourished rats (i.e., impairments in retrieving the information processed during the learning task; Figure 2C).

\section{Discussion}

Malnourished rats had a decreased body weight gain compared to control ones throughout the phases of nutritional treatment even after the period of nutritional recovery (from the $50^{\text {th }}$ day to the beginning of the learning tests, at the $70^{\text {th }}$ day of age). Malnourished rats' body weight corresponded to $35 \%$ of the control rats' body weight at the last week of lactation period and reached $66 \%$ of control's body weight at the end of the experiments, remaining considerably lower despite the nutritional recovery treatment. This difference in weight up to adult age can be explained by the fact that the body weight of adult rats is determined during the gestation and lactation periods, and it depends on the nutritional conditions existing during these periods (Passos et al., 2000). The reduced protein intake by the dam during lactation period causes quantitative and qualitative alteration in the milk source, including changes in the levels of the amino acids needed for pup growth and development (Cambraia, Vannucchi, \& Oliveira, 1997; Passos et al., 2000; Pine et al., 1994).

Several studies have demonstrated that severe postnatal protein malnutrition ( $6 \%$ protein diet) starting at birth or at weaning, and maintained throughout the period of development of the SNC and sexual maturity (50 days of age), leads to malnutrition in rats, which can be clearly demonstrated by the significant deficit in body weight gain over the treatment (nutritional insult), since this physical parameter is always accompanied by lower brain weight and smaller body length (for a review see Alamy \& Bengel- loun, 2012; Resnick, Morgane, Hasson, \& Miller, 1982). In earlier studies, correlation analyses between body and brain weights are most frequently used in order to determine the nutritional status of malnourishment in early life as an overt physical development parameter (Alamy \& Bengelloun, 2012; Lima, Oliveira, Lachat, Dal-Bo, \& Almeida, 1993; Wolf et al., 1986). Thus, according to the extensive literature discussed by Alamy and Bengelloun (2012) and by Lima et al., (1993), it is evident that body weight has been widely used as the main physical parameter for evaluating the malnutrition effects, both in experimental animals and in human studies.

The results found, according to previous mentioned studies indicated both memory and learning deficits provoked by protein malnutrition imposed during the lactation and post-lactation phases. Learning and memory can be assessed at the performance data from the 24 successive trials at the MWM task and the long-lasting reference memory is analyzed according to the $26^{\text {th }}$ trial data at the Memory Retention Test. Previous studies have also demonstrated that the performance of malnourished rats was impaired compared to control rats both during learning acquisition and memory retention test (Fukuda et al., 2002; Fukuda et al., 2007; Valadares et al., 2010; Zhang et al., 2010) and other studies have presented results related to functional and morphological changes in the hippocampal formation as a consequence of early protein malnutrition (Fukuda et al., 2007; Matos et al., 2011) and protein deprivation in adulthood (Lukoyanov \& Andrade, 2000).

Early malnourished rats reared in group, when stressed, can present an increased anxiety as observed in the EPM test, with a significant decrease in exploration (time and entries) at the open arms of the maze, while no significant behavioral alterations was observed in control animals due to acute stress or social isolation (Françolin-Silva \& Almeida, 2004).

Our results also demonstrated that the acute stress procedure, imposed before the spatial learning task, did not produce significant behavioral changes in control rats at this particular learning task, however, malnourished animals appeared to be more reactive to this procedure, in accordance to the above mentioned study, since they showed an improved performance in the execution of the task and, consequently, in learning acquisition when compared to malnourished non-stressed rats. According to previous researches discussed before, the modulation of hippocampal function by stress involves a dynamic process which is under the continuous influence of animal's perception about the environmental stressful event (Kim \& Diamond, 2002). Some studies have indicated that malnourished rats are more reactive to aversive or painful stimuli (Almeida \& De-Oliveira, 1994; Françolin-Silva \& Almeida, 2004; Rocinholi et al., 1997). On the basis of this proposition, the better performance of animals exposed to a stressful situation, considered as a natural aversive event, may be explained as a natural reaction to a potentially harmful stimulus which, in malnourished animals, seems 
Vales, L. D. F. M., Fukuda, M. T. H. \& Almeida, S. S. (2014). Effects of Acute Stress on Learning and Memory Processes of Malnourished Rats.

to have protective effect against the alterations produced by early malnutrition.

Several studies have demonstrated that the responses of the organism to stress are modulated by neurochemical, physiological and behavioral changes and involve adaptive mechanisms that enable the organism to react in an effective manner to real or potential threats to survival (Kim \& Diamond, 2002; McEwen, 2000; McEwen \& Sapolsky, 1995). Variables such as the context in which information is processed, or even the glycemic status of the organism, interfere with the modulation of information by the CNS and, in a more direct manner, by the hippocampus, determining the precision of the occurrence of memory retention and consolidation (McEwen \& Sapolsky, 1995).

However, data of the memory retention test $\left(26^{\text {th }}\right.$ trial) demonstrated impaired performance in both, stressed and non-stressed malnourished rats. The results revealed that the positive effects of acute stress on the processes of learning acquisition were circumstantial, restricted to learning phase, and that the effects of malnutrition on memory processing were not long-lasting.

On the other hand, in Experiment II, in which stress was imposed during the period of learning consolidation (i.e. immediately after each experimental session, there was no difference in performance between stressed and non-stressed rats in the same nutritional group). Both the $\mathrm{M}$ and SM groups presented longer latencies compared to $\mathrm{C}$ and $\mathrm{SC}$ rats in all stages of the test. These data revealed impaired performance of malnourished rats during the learning acquisition phase and reference spatial memory deficits at the memory retention test, although all animals were able to perform the task, as demonstrated by the reduction of the time spent to find the escape platform over the trials and by the total time spent on the target quadrant during the probe trial. A similar effect of differential performance of malnourished rats, compared to control ones, was reported in a previous study using the MWM to investigate learning and memory after an amnesic treatment (Fukuda et al., 2007). In that study, malnourished rats showed impaired performance in the MWM only when an amnesic drug (scopolamine) was administered before the beginning of the task, but no impairment was observed when the drug was injected after the experimental sessions (during learning consolidation). Therefore, our data suggest that an acute aversive event, imposed immediately after the session during the learning phase, did not represent a meaningful event capable of producing changes on spatial learning and memory processes of acquisition, consolidation or recall of previously acquired information.

Regarding the probe trial task, the greater percentage of navigation time spent in the target quadrant (QI) indicates that animals of all groups were able to learn the task in the water maze, despite performance differences. The only significant difference due to nutritional condition was a shorter navigation time in the target quadrant in $\mathrm{M}$ rats tested in Experiment I, as compared to other groups.
Nevertheless, $\mathrm{M}$ rats spent more time in the target quadrant than in the other three quadrants during the probe trial.

Considering several prior studies, it is plausible that the behavioral changes observed may be due to morphological, biochemical and/or functional alterations in the Central Nervous System (Almeida et al., 1996a; Bedi, 1991; Cintra et al., 1990; Galler et al., 1995; Huang et al., 2003; Lukoyanov \& Andrade, 2000; Matos et al., 2011; Morgane et al., 1993; Morgane et al., 2002; Zhang et al., 2010), specifically on stress response regulation (Camargo, Nascimento, \& Almeida, 2008; Françolin-Silva \& Almeida, 2004; Rocinholi et al., 1997), observed in prenatal (Almeida, Tonkiss, \& Galler, 1996b; Almeida, Tonkiss, \& Galler, 1996c; Morgane et al., 1993) and postnatal malnutrition (Almeida et al., 1991; Camargo \& Almeida, 2005; Castro, Tracy, \& Rudy, 1989; Fukuda et al., 2002; Fukuda et al., 2007; Valadares et al., 2010).

In conclusion, when the stress procedure was carried out following each test session during the learning acquisition phase, no effects of stress were found (i.e. stressed and non-stressed groups had the same performance). However, in previously malnourished rats, an acute stress episode, before the execution of spatial learning and memory tasks, affects positively the acquisition of learning, as demonstrated in the Morris maze. Memory retention and recall was unchanged in malnourished group when compared to control, despite the acute stress procedure.

\section{References}

Alamy, M., \& Bengelloun, W. A. (2012). Malnutrition and brain development: An analysis of the effects of inadequate diet during different stages of life in rat. Neuroscience and Biobehavioral Reviews, 36, 1463-1480. doi:10.1016/j.neubiorev.2012.03.009

Almeida, S. de S., \& De-Oliveira, L. M. (1994). Acquisition and extinction of jumping, two-way shuttle-box and bar press avoidance responses in malnourished rats: Effects of shock intensity. Brazilian Journal of Medical and Biological Research, 10, 2443-2452.

Almeida, S. de S., De-Oliveira, L. M., \& Graeff, F. G. (1991). Early life protein-malnutrition changes exploration of the elevated plus-maze and reactivity of anxiolytics. Psychopharmacology, 103, 513-518. doi:10.1007/BF02244251

Almeida, S. de S., Tonkiss, J., \& Galler, J. R. (1996a). Malnutrition and reactivity to drugs acting in the central nervous system. Neuroscience and Biobehavioral Reviews, 20, 389 402. doi:10.1016/0149-7634(95)00054-2

Almeida, S. de S., Tonkiss, J., \& Galler, J. R. (1996b). Prenatal protein malnutrition affects avoidance but not escape behavior in the elevated $T$-maze test. Physiology \& Behavior, 60(1), 191-195. doi:10.1016/0031-9384(95)02209-0

Almeida, S. de S., Tonkiss, J., \& Galler, J. R. (1996c). Prenatal protein malnutrition affects the social interactions of juvenile rats. Physiology \& Behavior, 60(1), 197-201. doi:10.1016/0031-9384(95)02236-8

Barnes, R. H., Neely, C. S., Kwong, E., Labadan, B. A., \& Franková, S. (1968). Postnatal nutritional deprivations as determinants of adult rat behavior toward food, its consumption and utilization. Journal of Nutrition, 96, 467-476. 
Bedi, K. S. (1991). Effects of undernutrition during early life on granule cell numbers in the rat dentate gyrus. The Journal of Comparative Neurology, 311, 425-433. doi:10.1002/ cne.903110311

Bedi, K. S. (1992). Spatial learning ability of rats undernourished during early postnatal life. Physiology \& Behavior, 51, 10011007. doi:10.1016/0031-9384(92)90084-F

Camargo, L. M. M., \& Almeida, S. S. (2005). Early postnatal protein malnutrition changes the development of social play in rats. Physiology and Behavior, 85, 246-251. doi:10.1016/j. physbeh.2005.03.025

Camargo, L. M., Nascimento, A. B., \& Almeida, S. S. (2008). Differential response to gepirone but not to chlordiazepoxide in malnourished rats subjected to learned helplessness. Brazilian Journal of Medical and Biological Research, 41(1), 54-59. doi:10.1590/S0100-879X2006005000187

Cambraia, R. P. B., Vannucchi, H., \& Oliveira, L. M. (1997). Foods intake and weight of lactating rats maintained on different protein-calorie diets, and pup growth. Brazilian Journal oh Medical Biological Research, 30, 985-988. doi:10.1590/ S0100-879X1997000800012

Castro, C. A., Tracy, M., \& Rudy, J. W. (1989). Early life undernutrition impairs the development of the learning and short-term memory process mediating performance in a conditional-spatial discrimination task. Behavioural Brain Research, 32, 255-264. doi:10.1016/S0166-4328(89)80058-0

Cintra, L., Díaz-Cintra, S., Galvan, A., Kemper, T., \& Morgane, P. J. (1990). Effects of protein undernutrition on the dentate gyrus in rats of three age groups. Brain Research, 532, 271277. doi:10.1016/0006-8993(90)91769-D

Crnic, L. S., \& Chase, H. P. (1978). Models of infantile malnutrition in rats: Effects on milk. Journal of Nutrition, 108, 1755-1760.

D’Hooge, R., \& De Deynn, P. P. (2001). Applications of the Morris water maze in the study of learning and memory. Brain Research Reviews, 36, 60-90. doi:10.1016/S01650173(01)00067-4

Dronjak, S., Gavrilović, L., Filipović, D., \& Radojcić, M. B. (2004). Immobilization and cold stress affect sympatho-adrenomedullary system and pituitary-adrenocortical axis of rats exposed to long-term isolation and crowding. Physiology \& Behavior, 81(3), 409-415. doi:10.1016/j.physbeh.2004.01.011

Fukuda, M. T. H., Françolin-Silva, A. L., \& Almeida, S. S. (2002). Early postnatal protein malnutrition affects learning and memory in the distal but not in the proximal cue version of the Morris water maze. Behavioral Brain Research, 133, 271-277. doi:10.1016/S0166-4328(02)00010-4

Fukuda, M. T. H., Françolin-Silva, A. L., Hernandes, A. S., Valadares, C. T., \& Almeida, S. S. (2007). Effects of early protein malnutrition and scopolamine on learning and memory in the Morris water maze. Nutritional Neuroscience, 10(5-6), 251-259. doi:10.1080/10284150701723818

Françolin-Silva, A. L., \& Almeida, S. S. (2004). The interaction of housing condition and acute immobilization stress on the elevated plus-maze behaviors of protein-malnourished rats. Brazilian Journal of Medical and Biological Research, 37(7), 1035-1042. doi:10.1590/S0100-879X2004000700013

Galler, J. R., Shumsky, J. S., \& Morgane, P. J. (1995). Malnutrition and brain development. In W. A. Walker \& J. Watkins (Eds.), Nutrition in Pediatrics: Basic science and clinical applications ( $2^{\text {nd }}$ ed., pp. 194-210). Philadelphia, PA: B.C. Decker.
Hemb, M., Cammarota, M., \& Nunes, M. L. (2010). Effects of early malnutrition, isolation and seizures on memory and spatial learning in the developing rat. International Journal of Developmental Neuroscience, 28, 303-307. doi:10.1016/j. ijdevneu.2010.03.001

Hernandes, A. S., Françolin-Silva, A. L., Valadares, C. T., Fukuda, M. T. H., \& Almeida, S. S. (2005). Effects of different malnutrition techniques on the behavior of rats tested in the elevated T-maze. Behavioural Brain Research, 162, 240-245. doi:10.1016/j.bbr.2005.03.008

Huang, L. T., Lai, M. C., Wang, C. L., Wang, C. A., Yang, C. H., Hsieh, C. S., ... Yang, S. N. (2003). Long-term effects of early-life malnutrition and status epilepticus: Assessment by spatial navigation and CREB (Serine-133) phosphorylation. Developmental Brain Research, 145, 213-218. doi:10.1016/j. devbrainres.2003.08.002

Kim, J. J., \& Diamond, D. M. (2002). The stressed hippocampus, synaptic plasticity and lost memories. Nature Reviews Neuroscience, 3, 453-462. doi:10.1038/nrn849

Laus, M. F., Vales, L. D. M. F., Costa, T. M. B., \& Almeida, S. S. (2011). Early postnatal protein-calorie malnutrition and cognition: A review of human and animal studies. International Journal of Environmental Research and Public Health, 8, 590-612. doi:10.3390/ijerph8020590

Lima, J. G., Oliveira, L. M., Lachat, J. J., Dal-Bo, C. M. R., \& Almeida, S. S. (1993). Comparison of the effects of lab chow and casein diets based on body and brain development of rats. Brazilian Journal oh Medical Biological Research, 26, 1069-1076.

Lukoyanov, N. V., \& Andrade, J. P. (2000). Behavioral effects of protein deprivation and rehabilitation in adult rats: Relevance to morphological alterations in the hippocampal formation. Behavioural Brain Research, 112, 85-97. doi:10.1016/S01664328(00)00164-9

Margis, R., Picon, P., \& Cosner, A. F. (2003). Relação entre estressores, estresse e ansiedade. Revista de Psiquiatria, 25(1), 65-74. doi:10.1590/S0101-81082003000400008

Matos, R. J., Orozco-Solís, R., Lopes de Souza, S., Manhães-deCastro, R., \& Bolaños-Jiménez, F. (2011). Nutrient restriction during early life reduces cell proliferation in the hippocampus at adulthood but does not impair the neuronal differentiation process of the new generated cells. Neuroscience, 196, 16-24. doi:10.1016/j.neuroscience.2011.08.071.

McEwen, B. S. (2000). The neurobiology of stress: From serendipity to clinical relevance. Brain Research, 886, 172-189. doi:10.1016/S0006-8993(00)02950-4

McEwen, B. S., \& Sapolsky, R. M. (1995). Stress and cognitive function. Current Opinion in Neurobiology, 5(2), 205-216. doi:10.1016/0959-4388(95)80028-X

Morgane, P. J., Austin-LaFrance, R. J., Bronzino, J. D., Tonkiss, J., Díaz-Cintra, S., Cintra, L., ...Galler, J. R. (1993). Prenatal malnutrition and development of the brain. Neuroscience and Biobehavioral Reviews, 17(1), 91-128. doi:10.1016/S01497634(05)80234-9

Morgane, P. J., Mokler, D. J., \& Galler, J. R. (2002). Effects of prenatal protein malnutrition on the hippocampal formation. Neuroscience and Biobehavioral Reviews, 26(4), 471-483. doi:10.1016/S0149-7634(02)00012-X

Morris, R. G. (1981). Spatial localization does not require the presence of local cues. Learning and Motivation, 12, 239-260. doi:10.1016/0023-9690(81)90020-5

O'Keefe, J. B., \& Nadel, R. (1978). The hippocampus as a cognitive map. Oxford, UK: Clarendon Press. doi:10.1016/ S0272-4944(81)80021-7 
Olton, D. S. (1979). Mazes, maps and memory. American Psychology, 34, 583-596.

Passos, M. C. F., Ramos, C. F., \& Moura, E. G. (2000). Short and long term effects of malnutrition in rats during lactation on the body weight of offspring. Nutrition Research, 11(20), 1603-1612. doi:10.1016/S0271-5317(00)00246-3

Pine, A. P., Jessop, N. S., \& Oldham, J. D. (1994). Maternal protein reserves and their influence on lactational performance in rats: The effect of dietary protein restriction and stage of lactation on milk composition. Brazilian Journal Nutrition, 72, 815-830. doi:10.1079/BJN19940087

Quevedo, J., Feier, G., Agostinho, F. R., Martins, M. R., \& Roesler, R. (2003). Consolidação da memória e estresse póstraumático. Revista Brasileira de Psiquiatria, 25(1), 25-30. doi:10.1590/S1516-44462003000500007

Reeves, P. G., Nielsen, F. H., \& Fahey, G. C. J. (1993). AIN93 purified diets for laboratory rodents: Final report for the American Institute of AIN-76 rodent diet. Journal of Nutrition, 123, 1939-1951.

Resnick, O., Morgane, P. J., Hasson, R., \& Miller, M. (1982). Overt and hidden forms of chronic malnutrition in the rat and their relevance to man. Neuroscience \& Biobehavioral Reviews, 6, 55-75. doi:10.1016/0149-7634(82)90007-0

Rocinholi, L. F., Almeida, S. S., \& De-Oliveira, L. M. (1997). Response threshold to aversive stimuli in stimulated early protein-malnourished rats. Brazilian Journal of Medical and Biological Research, 30, 407-413. doi:10.1590/S0100879X1997000300016

Rosa, M. L., Guimarães, F. S., De-Oliveira, L. M., Padovan, C. M., Pearson, R. C., \& Del Bel, E. A. (2005). Restraint stress induces beta-amyloid precursor protein mRNA expression in the rat basolateral amygdala. Brain Research Bulletin, 65(1), 69-75. doi:10.1016/j.brainresbull.2004.11.011

Santucci, L. B., Daud, M. M., Almeida, S. S., \& De-Oliveira, L. M. (1994). Effects of early protein malnutrition and environmental stimulation upon the reactivity to diazepam in two animal models of anxiety. Pharmacology, Biochemistry and Behavior, 49(2), 393-398. doi:10.1016/0091-3057(94)90439-1

Valadares, C. T., Fukuda, M. T., Françolin-Silva, A. L., Hernandes, A. S., \& Almeida, S. S. (2010). Effects of postnatal protein malnutrition on learning and memory procedures. Nutritional Neuroscience, 13, 274-282. doi:10.1179/147683 010X12611460764769

Wolf, C., Almli, C. R., Finger, S., Ryan, S., \& Morgane, P. J. (1986). Behavioral effects of severe and moderate early malnutrition. Physiology \& Behavior, 38(5), 725-730. doi:10.1016/0031-9384(86)90270-2

Zhang, Y., Li, N., \& Yang, Z. (2010). Perinatal food restriction impaired spatial learning and memory behavior and decreased the density of nitric oxide synthase neurons in the hippocampus of adult male rat offspring. Toxicology Letters, 193, 167-172. doi:10.1016/j.toxlet.2010.01.002 